\title{
Leather used in Furniture Upholstery
}

\author{
Koža za ojastučeni namještaj
}

\author{
Salah-Eldien Omer ${ }^{1 *}$ \\ Antuna Vramca 17, HR - 10000 Zagreb, Croatia \\ *sagzagreb@hi.htnet.hr
}

Stručni rad / professional paper

DOI: $10.34187 / \mathrm{ko} .69 .2 .2$

\begin{abstract}
Nowadays, there is a lot of leather material in the international market with different specifications and qualities. Since the furniture production, especially for the upholstered sofa, chairs, and similar products, are assembled and connected with a combination of glue and connectors, we need a specific selection for each product. Types of leather and their qualities are varied as well as the price. To assure the quality of the product we need to define many factors affecting the durability of the leather build in the furniture. Testing the planned leather is always recommended.
\end{abstract}

Keywords: furniture upholstery, leather, types, characteristics, testing.

\section{Sažetak}

Danas je, na međunarodnom tržištu, moguće pronaći mnoge vrste koža i koži sličnih materijala različitih specifikacija i razine kvalitete. Kako se u proizvodnji namještaja, a posebice ojastučenih sofa, stolaca i sličnih proizvoda, primjenjuju ljepilo i metalni spojevi, potrebno je za svaki proizvod odabrati odgovarajuće materijale. Pritom vrste koža, njihova kvaliteta, kao i pripadajuća cijena variraju. Da bi se osigurala kvaliteta gotovog proizvoda, nužno je precizno definirati čimbenike koji izravno utječu na trajnost kože ugrađene u namještaj. Stoga se ispitivanje odabranih koža uvijek preporuča.

Ključne riječi: ojastučeni namještaj, koža, vrste, svojstva, ispitivanje.

\section{Introduction}

The global leather industry is composed of three sectors of activity: anima husbandry and slaughter, tanning, and product manufacturing. Tanning is the stage in which raw leather is processed and made more durable so that it doesn't decompose in your living room. Tanning usually consists of following major processes:

Wet blue production (so-called because the semi-finished hide is given a chrome bath which imparts a bluish tint). This process involves removing unwanted substances (salt, flesh, hair, and grease) from a rawhide (by soaking in a bath of lime and sodium sulfide to dissolve hair and flesh), trimming it, treating it to impart the desired grain and stretch, and finally soaking it in a chrome bath to prevent decomposition. This step is far more polluting than finishing generating $90 \%$ of the water pollution associated with leather tannins finishing.

Finishing involves splitting, shaving, re-tanning, and dying the wet blue. Often leather is advertised as being "aniline-dyed". That means the leather is dyed for colour without any pigments applied. These dyes enhance the subtle variations of each hide and the leather does not lose any structure or grain pattern. It is often considered to be of a higher quality than other types of dyed leather because aniline dyed leathers develop a distinctive patina over time. Only premium hides with the most pleasing colour and texture are selected for this category, less than $5 \%$ of all upholstery hides in the world.

Semi-aniline also referred to as "Aniline Plus", is also advertised. These leathers are first dyed in penetrating aniline dyes. Then a topcoat is applied to even out the colour of the hide surface. The topcoat also serves to create fading- and soil-resistant pieces. They retain a great amount of the softness of aniline-dyed hides because the natural top grain is left intact. A much larger proportion of the worldwide hide supply is suitable for this class of leather and as a result, they are more moderately priced than pure anilinedyed hides.

The most important aspect you need to consider when you are selecting leather for furniture is leather grain. This is the surface material where people will be sitting on. Do not be deceived by the term top grain. Most people assume top-grain leathers are the best when, in fact, the term is describing the top layer being sanded off and a fake grain being stamped onto the hide during the tanning process.

To make sure you are purchasing only the best grain, choose leathers that have been allowed to retain the original animal grain. Below details of the different types of leather on leather furniture [1]

Choosing the colour of a new leather recliner or leather chairs is important for maintaining the appeal of your decor. The colour you select for your leather furniture should be the one you are using the least in a colour scheme. The colours of dyed leather can be brilliant. If the accessories, wallpaper, and flooring all have the same colour as your leather couch, you may find the furnishings to be overbearing.

The colour of your new leather couch can also be subtle and still add a great level of appeal. When choosing colours for your leather sofa, consider what texture you prefer. Choosing semi-aniline leather allows a softer texture with a small amount of finish for adding a low level of protection against stains. Velvety, suede leathers have been sanded a great deal more than other leather choices. Suede provides a tremendous softness to the touch, but it is also the least resistant to stains than any other choice.

Leather that is too shiny can be a bad choice. Choosing leather that is not shiny and looks worn is best and more likely to be real leather. The patina leather gathers over time gives it a worn and classy look you can only achieve with properly tanned animal hides. Overstuffed styles with a few years of patina present a beautiful, well preserved vintage appearance. Many smoother styles can also gather patina around areas of hand tufting. If you are interested in buying a leather piece that has the worn, comfortable appearance of the patina, you might consider buying a used piece. Some retailers offer used leather furnishings in great shape and they are sometimes more affordable.

If you are in the market for a leather sofa, one of the first questions you have probably asked yourself is, how can you tell when leather furniture is upholstered with real genuine leather? If you have done your homework you will find that there are multitudinous ways that leather can be classified. There are also a number of terms that imply genuine leather, but in reality, refer to some type of synthetic material that looks and maybe even feels like leather. This brief article will provide 5 basic tips that will help you become better equipped to tell the difference between artificial leather and the real thing.

\section{Types of leather for furniture}

The major producers of leather furniture are always following the architect or designer trends. Producers of leather for furniture usage are also trying 
to satisfy the qualities and design needed by the furniture producers (Figure 1). We are going to mention the most present leather types in the international market.

2.1. Faux leather, as the name suggests, is not real leather. It is man-made leather made from synthetic materials such as plastic and rubber coated fabric. Faux leather has come a long way as the technology has resulted in great improvements in the material composition, thus increasing the comfort level of such sofas. It is durable, looks like original leather, and is the cheapest type of leather for furniture.

2.2. Bonded leather is a cheaper manufacturer's first line of attack in selling you the look and feel of leather for a "great deal." Unfortunately, bonded leather is hardly leather at all by definition, it has to be only $17 \%$ leather. So leather is to bonded leather what chicken is to chicken McNuggets (or pressboard to wood, or dryer lint to fabric). In other words, it's processed beyond recognition. To create bonded leather, leather scraps and fibres are mixed and then formed into a roll using adhesives or other bonding materials. In fact, the manufacturing process is very similar to making paper. After the roll is formed, it goes under drying equipment to reduce the moisture content. Since it usually contains only 10 to 17 percent leather fibres, some industry experts do not consider it real leather and express concerns with it being marketed as such. Bonded leather does have its advantage as a furniture material. Firstly, it is highly durable. Secondly, it contains low levels of environmentally unsafe formaldehyde as it doesn't undergo chemical tanning and is, therefore, suitable for people with leather allergies. Lastly, bonded leather furniture is significantly cheaper than real leather. In reality, a person sitting on bonded leather is not sitting on leather at all, only plastic. And unlike real top-grain leather, the ground-up hide and plastic will never acclimate to your body temperature or get better with age.

2.3. Bi-cast leather (also known as bi-cast, bycast, or PU leather) is what most people consider the next step up in quality.
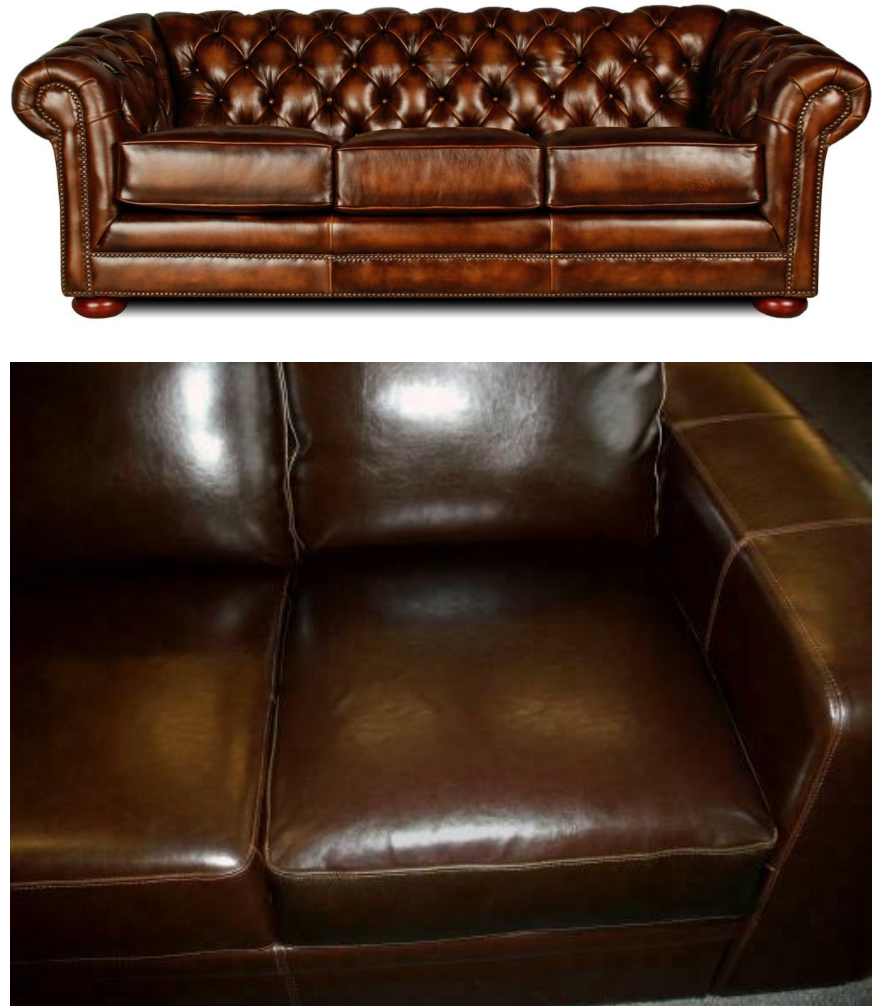

Figure 1. Example of most common leather use for sofa

Before a hide is put into production, it is cut horizontally into layers. These layers consist of the top grain (the top layer that maintains the actual surface of the cow's hide where the pores and hair follicles used to be) and then every split below that.

$\mathrm{Bi}$-cast leather is a layer of the split that was too thin or flawed for normal use and that, like bonded leather, is completely sealed on top with a layer of polyurethane. Like bonded leather, no actual point of contact is possible between the natural leather and your skin and, therefore, bi-cast doesn't demonstrate any of the same wear or comfort attributes of top grain.

That being said, bi-cast can still serve as an economical alternative for people wanting the look of leather without the price. Another benefit might be that bi-cast and bonded leather wipe up easily (since they have plastic surfaces) and you won't run into many of the food/drink stain issues you may experience with upholstered furniture.

It is made by gluing a sheet of polyurethane colour to a split grain. It has the appearance of top grain leather, at a fraction of the cost. Bi-cast does not age well. In fact, it cracks and peels when exposed to too much friction. So, make sure that you purchase bi-cast furniture knowingly and not because you were led to believe it is real leather.

2.4. Split Grain, after the removal of the top grain, you get split leather from the remaining part of the hide. This leather is harder and cheaper than fullgrain leather. Split leather is comparatively more fragile and gets easily damaged if not handled properly. As mentioned before, a split is merely the lower layers of a hide underneath the top-grain. A split is still $100 \%$ real leather but does not have all of the characteristics of top-grain due to processing differences. When a split is made, it is initially lightcoloured and fuzzy or suede-like on both the top and bottom of the hide so that it won't look like top grain. On leather furniture, the traditional top-grain leather look is shiny, has natural variations in colour (as a hide is a natural product with variations in thickness and quality and, therefore, withstands dyes differently), has a smooth and soft hand (or feel), and natural "pebbling" (the unique bumps that vary depending on from which part of the cow the hide was taken). Because a split has none of these qualities, the split must be processed through various means to simulate the appearance and feel of top-grain leather. Although the result is still $100 \%$ leather, some softness is always lost through the processing procedures and natural variations in colour and pebbling are no longer evident as these hides are run through a uniform screen.

The leather, otherwise known as corrected grain or full grain pigmented, is taken from the outer layers of the hide and is the toughest leather type. Unlike full grain, top grain is usually buffed to remove any imperfections. Top grain leather furniture will typically be more expensive, but will have an incredibly soft feel and will be long-lasting. As stated above, the top grain is the smoothest, supplest, most natural, and best kind of furniture leather your money can buy. Each hide is as individual and unique as a fingerprint. Real, top grain is comprised of about $12-14 \%$ water. For this reason, topgrain leather acclimates quickly to your body temperature. Leather is a natural product and thus breathes like one

Top-grain comes in two different grades: aniline and semi-aniline. Aniline is the most natural and has no protective coatings or treatments that alter its natural feel. Because of this, it's the softest but also susceptible to stains, while semi-aniline may be coated with a protective topcoat. Many people who have experienced "sweating" on leather and are therefore turned off by the idea of leather furniture are referring to a leather product like bonded leather or vinyl. This is especially true in car seats that sit in the sun for hours.

2.5. Nubuck is top grain cattle rawhide leather that has been sanded or buffed on the grain side, giving it an appearance similar to velvet and suede. It has a more uniform appearance because the exterior is sprayed with a finishing agent. It is cheaper as compared to full-grain leather. However, nubuck furniture is fragile in nature and requires careful maintenance. $A$ waterproofing treatment is mandatory to keep the material looking good.

2.6. Full Grain is the term full grain describes leathers retaining the imprints original to the hide and the animal it was taken from (Figure 2)

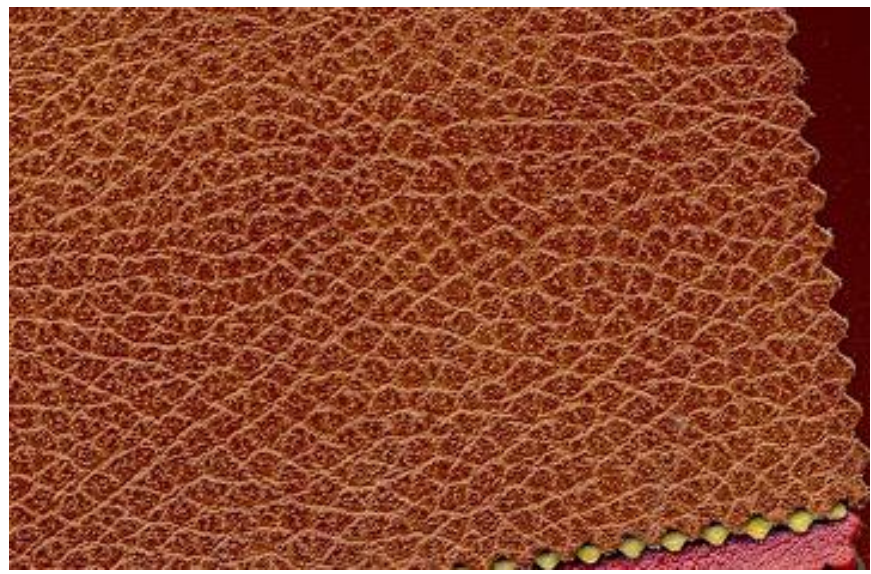

Figure 2. A sample of good quality leather which rarely used in furniture

Full grain leather is the leather that is formed just by removing the hair present on the skin of the hide. The whole hide is used, rather than just 
some layers of it. Except for hair removal and soaking in some form of natural dye like aniline vegetable dye, it is untreated leather. No polishing and finishing are done to the grain. Although there may be imperfections on the leather, as it retains all of the original texture and markings of the original hide, this kind of grain tends to look and feel better with time. As such, it is usually the most expensive kind of leather furniture available.

\section{How to identify if a piece of furniture is made from real leather?}

We will provide 5 basic tips that will help you become better equipped to tell the difference between artificial leather and the real one. Before moving forward there a couple of myths that need to be dispelled. First, the myth that you can simply tell genuine leather from synthetic by touch is not true at least not in the simplest sense. The processes and materials used to make synthetic leather have come a long way over the years and the look and feel of these synthetics are very close to the authentic article. This doesn't mean that touch and feel do not play a role in being able to determine whether the leather sectional that you are considering purchasing is real or not. It simply means don't look for touch to be a primary indicator.

Now, there some synthetics that are of such poor quality that you will be able to touch them and immediately tell. You don't need the help of this article to figure that one out.

Second, don't expect a salesman to be upfront with you in revealing whether an article is a genuine leather or not. The leather furniture industry has developed some rather tricky terminology that infers that certain pieces of leather furniture are real leather when actually it is some form of synthetic leather or a mixture of leather and synthetic material.

This article is not an attack on synthetic leather; it serves its purpose in the right situation and under the right light. The thing is that when you are out looking to make a significant purchase for your home, whether it is a leather sofa or a leather recliner, you want to be able to know what you are spending your money on. Being able to distinguish between a synthetic leather sectional and the real thing is paramount in determining true value.

Below you will find 5 valuable tips that will help you distinguish between a real leather sofa and imitation leather furniture.

\section{Read the tag}

This may sound a little obvious, but it is the first thing that you should do. Many manufacturers, especially those that are reputable, will have the material and construction information on the tag. If it is a genuine leather chair, sofa, or recliner, it may be stated on the tag. The reason that it is a good idea to read the tag is the fact it is illegal to advertise or represent a product to be something it is not.

Unless you are dealing with some very despicable dealers, that tag will be accurate. Obviously, this only works if the tag is on the sofa, and all manufacturers don't verify article authenticity on the tag.

\section{Observe the grain}

Leather is a natural material and it should have some imperfections in its grain. The grain should not have any consistent or repetitive patterns in it. Look for the presence of natural scars.

\section{Take the time to feel the leather}

As mentioned earlier in this article, simply feeling the leather is not always enough to determine if the leather sofa you are looking at is made of real leather. Leather furniture does have a distinct feel. It all depends on how much the hide has been processed. If the animal hide has been embossed, it will not necessarily have a very genuine feel to it, but it is still considered genuine leather. This is why feel alone, doesn't work. Real leather is pliable and supple. You should be able to press it down and feel it give some.

\section{Check the backing to see if it's cloth}

Vinyl and other synthetic leathers are always backed with some form of cloth. One of the most simple ways to determine if you are dealing with real leather furniture is to check the backing. Examine the cut seams underneath the sofa. Do you detect animal hide or some form of cloth?

\section{Smell the leather furniture}

Leather has a very distinct smell that is impossible to imitate. Find some real leather samples to familiarize yourself with the smell. This way you will be able to recognize the smell of genuine leather[2]. When you are looking to buy a leather sofa or any other type of leather furniture (Figure 3) you want to be sure that you are getting what you pay for. These tips will help you to be better prepared.

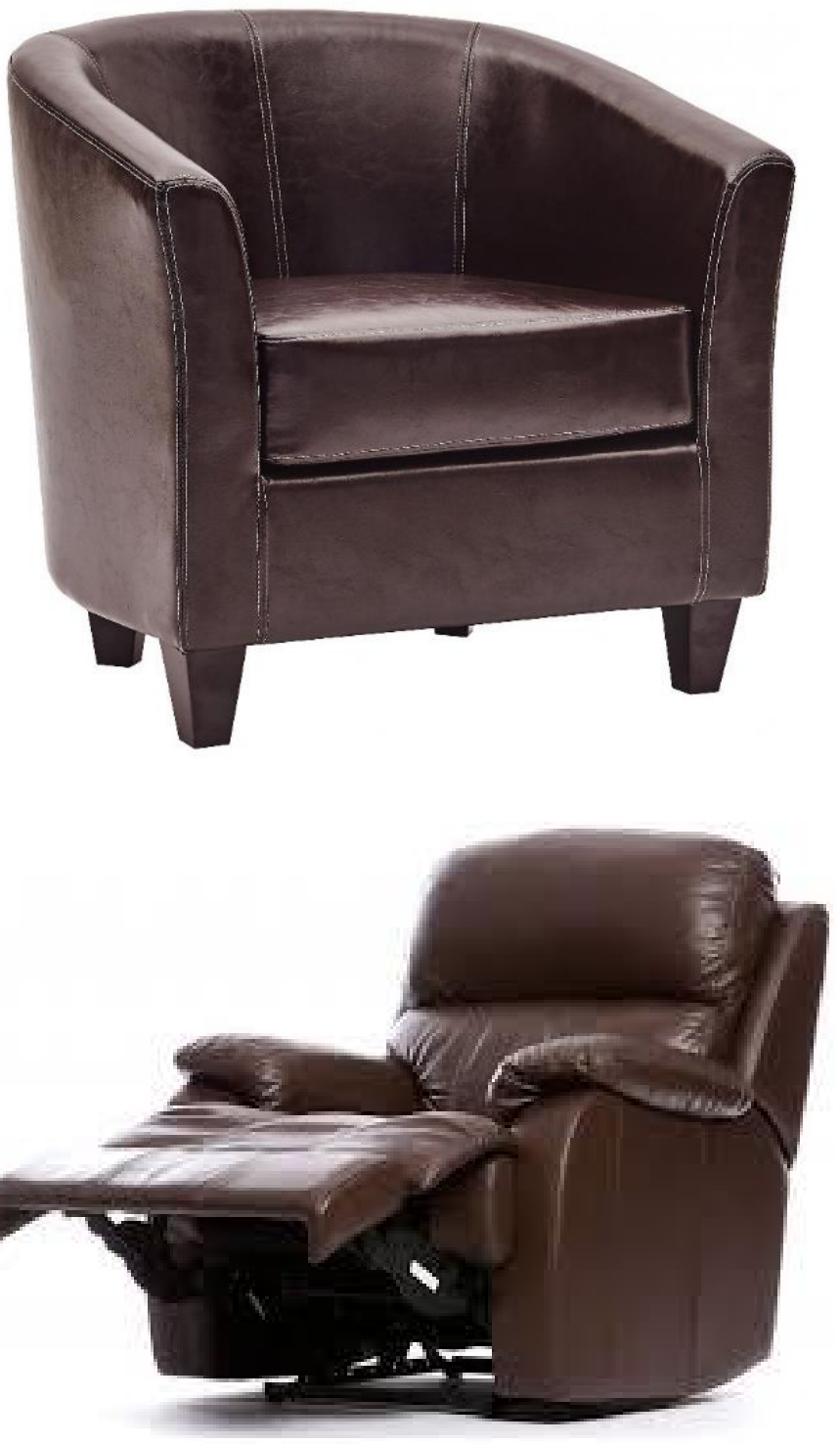

Figure 3. Paisley bonded leather tube chair and recliner leather chair

\section{Testing of leather for furniture}

It's very important to test the purchased leather for your furniture to assure the suitability of your products as well as the quality you offer.

\section{Physical Testing:}

Eurofins | BLC's range of physical leather testing includes tests to establish leather performance and quality for a range of applications:

- $\quad$ BS EN ISO 2589:2016 - Thickness

- $\quad$ BS EN ISO 17186:2011 - Finish thickness (thickness of surface coatings)

- $\quad$ BS EN ISO 17235:2015 - Softness

- $\quad$ BS EN ISO 2420:2017 - Density

- $\quad$ BS EN ISO 5402-1:2017 - Flex resistance by flexometer method (Bally flex)

- $\quad$ BS EN ISO 5402-2:2015 - Determination of flex resistance by the vamp flex method 
- $\quad$ BS EN ISO 4684:2005 - Determination of volatile matter (moisture)

- $\quad$ ASTM D6116-18 - Standard Test Method for Blocking

- $\quad$ BS EN ISO 4045:2018 - Determination of $\mathrm{pH}$ value and difference figure of an aqueous extract

\section{Water Spotting (Water Staining), Water Fastness \& Perspiration Testing:}

Eurofins | BLC can test a finished product or sample to measure the resistance to water spotting on the leather:

- $\quad$ BS EN ISO 105-E07:2010 \& BS EN ISO 15700:1999 - Spotting: water (water spotting)

- $\quad$ BS EN ISO 11642:2012 - Water (water fastness)

- $\quad$ BS EN ISO 105-E04:2013 \& BS EN ISO 11641:2012 - Perspiration

\section{Leather Finish Adhesion Testing (Wet \& Dry):}

Eurofins | BLC can test the adhesive properties of various finishes for leather, PU, PVC, and other synthetic alternatives:

- $\quad$ BS EN ISO 11644:2009 - Finish adhesion

\section{Leather Tear Strength Testing:}

Eurofins | BLC offer a variety of leather tear strength tests for multiple end uses:

- $\quad$ BS EN ISO 3376:2020 - Tensile strength and percentage extension

- $\quad$ BS EN ISO 3377-1:2011 - Tear load - single edge tear

- $\quad$ BS EN ISO 3377-2: 2016 - Tear load - double edge tear - Baumann

\section{Light Fastness*, Colour Fastness \& Colour Migration Testing:}

Eurofins | BLC provides a range of lightfastness, colourfastness, and migration tests for leather, textile, and synthetic alternatives. Eurofins | BLC tests can determine the resistance of fading, bleeding, running of dyes or pigments, and colour migration:

- $\quad$ BS EN ISO 105-B02:2014 - Light (light fastness)

- $\quad$ BS EN ISO 15701: 2015 - Staining of PVC (PVC migration)

\section{Rub Fastness Testing:}

Eurofins | BLC rub fastness testing measures the resistance of colours in leather to loss under rubbing:

- $\quad$ BS EN ISO 17700:2019 Part A \& B - Colour fastness to rubbing (rub fastness)

\section{Cold Crack Testing of the Leather Finish:}

Finish cracking can be a common leather problem that can be caused by specific environmental conditions, therefore Eurofins | BLC recommends that leathers are tested for their resistance to cracking:

- $\quad$ BS EN ISO 17233:2017 - Crack cold resistance

\section{Leather Dry-Cleaning \& Wash Fastness Tests:}

Where leather goods need to be dry cleaned or washed on a domestic or commercial scale, Eurofins | BLC can test their ability to resist fatigue, fading, and failure.

Specialist dry cleaning testing services available

- BS EN ISO 105-C06:2010 - Colour fastness to domestic and commercial laundering (colourfastness to washing)

\section{Abrasion Resistance Testing (Including Taber Method):}

Eurofins | BLC can test a range of leather types (including PU and synthetic alternatives) for their abrasion resistance:

Taber Method

- $\quad$ BS EN 13520:2002+A1:2004 - Abrasion resistance (Martindale) [3].
We usually recommend the EN norms for the producers in Europe for the approach of the methods and Institutions around

EN 1021 - 1/2: 2014: This standard applies throughout the EU and examines the reaction of a substance to a burning cigarette and a butane flame (a simulated match). It replaces a variety of national tests, including DIN 54342 - 1/2 in Germany and BS 5852: 1990 in Great Britain.

EN 1021 - part 1: In part 1 of the test, a burning cigarette is placed at the angle of the test model and is glowed in its entire length. After 60 minutes the fabric should not glow or burn.

EN 1021 - part 2: A $35 \mathrm{~mm}$ high butane flame represents a burning match and is also placed at the angle between the backrest and seat of the test model for 15 seconds. After the flame has been removed, the fabric should not start to burn within 2 minutes.

EN 13501 - part 1:2018 is similar to DIN 4102-1. The fire behaviour of building materials for use in construction is tested.

\section{Conclusions}

Since we tried to take a brief look at the leather in the International market, from the above represented data we can conclude the following:

- A wide spread of leather qualities can be found on the International for furniture production;

- The types of leather represented in this article are well accepted by furniture producers worldwide, and the most important aspect you need to consider when you are selecting leather in the furniture is leather grain;

- You will find 5 valuable tips that will help you distinguish between a real leather sofa and imitation leather furniture;

- For the assurance of the leather quality for the furniture, we represented several standards for testing leather;

- We consider the leather furniture around us is widely represented in the market but the high quality is mostly produced by order.

\section{References}

1. Care Instructions/SCP Life, https://news.scp.co.uk, Pristupljeno: 2020-12-12

2. Pocket Book for the leather Technologist, Fourth Edition, BASF Aktiengesellschaft 67056 Ludwigshafen Germany

3. Elizabeth Olsen: Can Leather Be Eco-Friendly...Ever?, Ecouterre, 19 October 2009 